\title{
Recombinant expression and purification of the 2,5-diketocamphane 1,2-monooxygenase from the camphor metabolizing Pseudomonas putida strain NCIMB 10007
}

\author{
Maria Kadow, Stefan Saß, Marlen Schmidt and Uwe T Bornscheuer
}

\begin{abstract}
Three different Baeyer-Villiger monooxygenases (BVMOs) were reported to be involved in the camphor metabolism by Pseudomonas putida NCIMB 10007. During (+)-camphor degradation, 2,5-diketocamphane is formed serving as substrate for the 2,5-diketocamphane 1,2-monooxygenase. This enzyme is encoded on the CAM plasmid and depends on the cofactors FMN and NADH and hence belongs to the group of type II BVMOs. We have cloned and recombinantly expressed the oxygenating subunit of the 2,5-diketocamphane 1,2-monooxygenase (2,5-DKCMO) in E. coli followed by His-tag-based affinity purification. A range of compounds representing different BVMO substrate classes were then investigated, but only bicyclic ketones were converted by 2,5-DKCMO used as crude cell extract or after purification. Interestingly, also (-)-camphor was oxidized, but conversion was about 3-fold lower compared to (+)-camphor. Moreover, activity of purified 2,5-DKCMO was observed in the absence of an NADHdehydrogenase subunit.
\end{abstract}

Keywords: Baeyer-Villiger monooxygenases, camphor, Pseudomonas putida NCIMB 10007, 2,5-diketocamphane 1,2monooxygenase, bicyclic ketones

\section{Introduction}

The discovery of the enzymatic Baeyer-Villiger reaction is closely connected to the exploration of the biodegradation of camphor (1) in Pseudomonads (Figure 1). Initial studies on the microbial decomposition of $(+)-\mathbf{1}$ by Pseudomonas putida NCIMB 10007 isolated from sewage sludge were already carried out in 1959 (Bradshaw et al. 1959) and the involved enzymes were separated and characterized during the following decade. In studies of the enzymatic lactonization of the intermediate 2,5-diketocamphane (3) from the $(+)$-camphorgrown organism it was shown that two enzyme fractions were responsible for the Baeyer-Villiger-monooxygenase (BVMO) catalyzed reaction step (Conrad et al. 1961,). The first enzyme turned out to be a FMN-coupled NADH-dehydrogenase [EC 1.6.8.1], while the second

\footnotetext{
* Correspondence: uwe.bornscheuer@uni-greifswald.de Department of Biotechnology and Enzyme Catalysis, Institute of Biochemistry, Greifswald University, Felix-Hausdorff-Str. 4, D-17487 Greifswald, Germany
}

(C) 2011 Kadow et al; licensee Springer. This is an Open Access article distributed under the terms of the Creative Commons Attribution License (http://creativecommons.org/licenses/by/2.0), which permits unrestricted use, distribution, and reproduction in any medium, provided the original work is properly cited. subunit was claimed to be a ketolactonase. Since mechanistic similarities to the chemical Baeyer-Villiger oxidation of bicyclic ketones (Meinwald and Frauenglass 1960) were detected, the nomenclature of the ketolactonase was changed to a BVMO. In 1965 a second lactonizing system for the degradation of $(-)-\mathbf{1}$ was found (Conrad et al. 1965a). Thus it was claimed that $(+)-1$ and its derivatives were only converted by the (+)-camphor induced 2,5-diketocamphane 1,2-monooxygenase (2,5-DKCMO), while (-)-1 is converted by the (-)-camphor induced 3,6-diketocamphane 1,6-monooxygenase (Jones et al. 1993) (Figure 1). Later it was claimed, that whichever enantiomer of camphor is given to the growth medium, both diketocamphane monooxygenases are induced (Gagnon et al. 1994). The ability to decompose camphor turned out to be inducible in several fluorescent Pseudomonads, where most of the involved enzymes, including both type II monooxygenases, are located on a $230 \mathrm{~kb}(165 \mathrm{MDa})$ plasmid (CAM plasmid, Figure 2) (Chakrabarty 1976). 


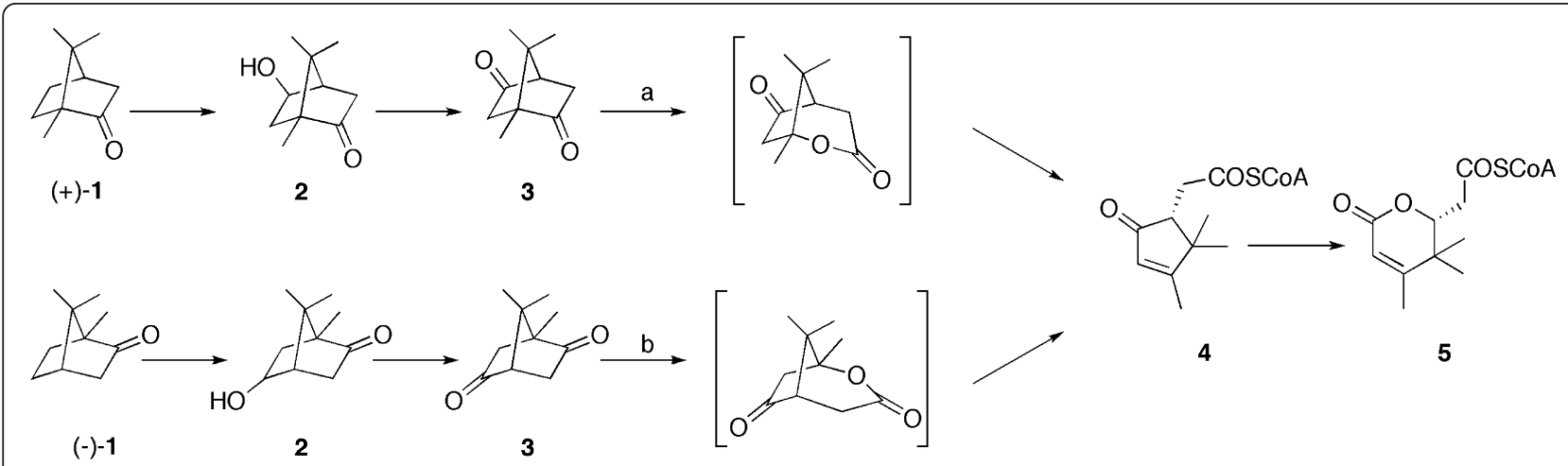

Figure 1 Camphor degradation in Pseudomonas putida NCIMB 10007: In the first step camphor (1) is hydroxylated by the P450 Cam ${ }^{-}$ monooxygenase (Unger et al. 1986,) followed by an oxidation by the 5-exo-alkohol dehydrogenase (Koga et al. 1989) yielding the corresponding diketocamphane (3). (+)-1 is degraded by the 2,5-dicetocamphane 1,2-monooxygenase (a), while (-)-1 requires the 3,6-diketocamphane 1,6monooxygenase (b). Both resulting lactones are unstable and lead to spontaneous formation of the 2-oxo- $\triangle 3-4,5,5$-trimethylcylopentenylacetic acid, which is further converted to a coenzyme A derivative (4), which is again a substrate for a third involved BVMO (2-oxo- $\triangle 3-4,5,5-$

trimethylcylopentenylacetic acid monooxygenase, often designated as MO2) (Ougham et al. 1983).

During the 1990s, several studies on the conversion of cyclic and bicyclic alkanones using whole Pseudomonas putida cells or partially purified enzymes of this organism were performed. Regarding the evolutionary predisposition of the three BVMOs involved in camphor metabolism, diketocamphane monooxygenases turned out to catalyze the efficient production of optically active bicyclic lactones in an enantiodivergent and highly selective manner (Gagnon et al. 1994,). Especially bicyclo [3.2.0.] ketones and norcamphor-derived compounds were investigated and benzyloxylactone, achieved from a norcamphor derivative, emerged as an important precursor for the insect antifeedant azadirachtin (Gagnon et al. 1994,; Gagnon et al. 1995b). A series of monocyclic ketones were further explored and 2-alkylcyclopentanones and 3-substituted cyclobutanones were converted with often complementary enantioselectivity in comparison to transformations with whole cells of Acinetobacter calcoaceticus, which was finally attributed to 2-oxo- $\Delta 3-4,5,5$-trimethylcylopentenylacetic acid monooxygenase (Gagnon et al. 1995a,; Grogan et al. 1993). These studies were performed with cells or cell-free extracts, which contained all three BVMOs or at least both diketocamphane monooxygenases. Even though separation of the distinct activities was tried by purification, the presence of impurities could not be excluded. Therefore, reproducible and reliable methods for separation and purification are required for the accurate characterization of these enzymes.

The availability of efficient cofactor recycling strategies for NADH-regeneration in BVMO-catalyzed oxidations, e.g. by the formate dehydrogenase from Candida boidinii, were also exploited. Moreover, coupling processes of horse liver alcohol dehydrogenase together with 2,5-DKCMO were used to produce optically active lactones starting from alcohol precursors (Gagnon et al. 1994; Gagnon et al. 1995b).

Several new BVMOs were investigated recently and while most of them refer to type I, which are FAD and NADPH-dependent, (Fraaije et al. 2005,; Rehdorf et al. 2007,; Völker et al. 2008,; Rehdorf et al. 2009) only a few examples for FMN/NADH-containing type II BVMOs were investigated up to now. A reason might be the challenging overexpression of these enzymes in a heterologous host, since in contrast to type I BVMOs the oxygenating and dehydrogenase subunits are distinct proteins.

So far all characterization and biocatalytic experiments with 2,5-diketocamphane 1,2-monooxygenase were performed using large scale cultivations of the wild type strain P. putida NCIMB 10007 with subsequent multiple purification and separation steps of the involved enzymes. We report here the first recombinant

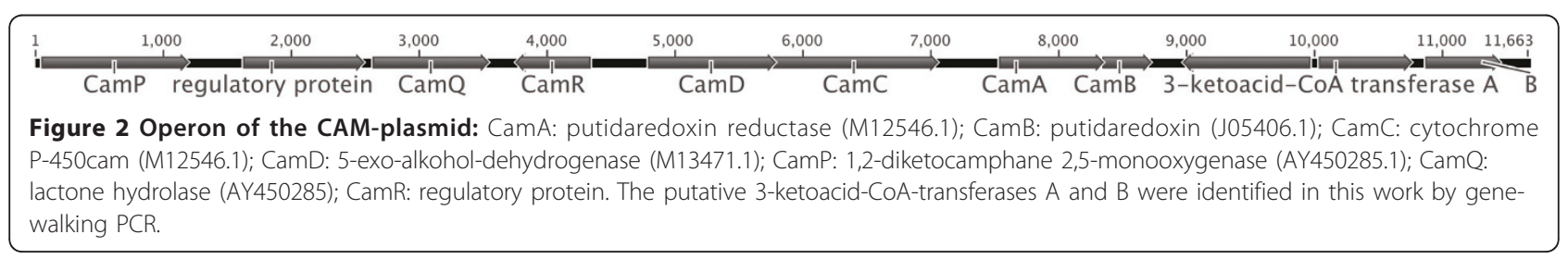


overexpression of the oxygenating 2,5-diketocamphane 1,2-monooxygenase from P. putida NCIMB 10007 in Escherichia coli followed by simplified purification via affinity chromatography and characterization of the enzyme.

\section{Material and methods}

\section{Enzymes, chemicals and media}

$\mathrm{Pfu}^{+}$-polymerase was obtained from Roboclon (Berlin, Germany) and dNTPs from Roth (Karlsruhe, Germany). Restriction enzymes were obtained from New England Biolabs (Beverly, MA, USA). For SDS-PAGE analysis, the prestained PAGE ruler plus from Fermentas (St. Leon-Rot, Germany) was used. All other chemicals were purchased from Fluka (Buchs, Switzerland), SigmaAldrich (Munich, Germany) or Acros Organics (Geel, Belgium). For DNA-purification from PCR, the MinElute PCR-purification Kit by Qiagen (Hilden, Germany) was used. Furthermore the Miniprep Kit from Qiagen was used for plasmid purification. HisTrap $5 \mathrm{~mL}$ FF columns and Sephadex G25 were obtained by GE Healthcare (Uppsala, Sweden). The plasmid pET-28b(+) was from Novagen (Darmstadt, Germany). The BCA kit was purchased from Interchim (Montluçon, France).

\section{Amplification and cloning}

Amplification of the 2,5-DKCMO gene was performed with chromosomal DNA containing the CAM-plasmid with oligonucleotides supplemented with restriction sites for $\mathrm{NdeI}$ at the $\mathrm{N}$-terminus and $\mathrm{XhoI}$ at the $\mathrm{C}$-terminus (NdeI_2,5-DKCMO_fw: 5'-GGAATTCATATGAAA TGCGGATTTTTCCATACCCC-3'; 2,5-DKCMO_XhoI_rv: 5'- CCGCTCGAGTCAGCCCATTCGAACCTT$\left.3^{\prime}\right)$. After initial denaturation for $5 \mathrm{~min}$ at $95^{\circ} \mathrm{C}$, the cycling program was followed for 25 cycles: $45 \mathrm{~s}, 95^{\circ} \mathrm{C}$ denaturation, $45 \mathrm{~s}, 58^{\circ} \mathrm{C}$ primer annealing, $70 \mathrm{~s}, 72^{\circ} \mathrm{C}$ elongation. The final elongation step was performed over 10 minutes at $72^{\circ} \mathrm{C}$. The resulting $1092 \mathrm{~kb}$ fragment was digested with NdeI and $\mathrm{XhoI}$ and ligated into pET-28b digested with the same enzymes. The resulting plasmid with a $\mathrm{N}$-terminal His-tag fusion was called pET-28_2,5-DKCMO (Figure 3).

\section{Bacterial strains and culture conditions}

P. putida NCIMB 10007 (equivalent to ATCC 17453) was purchased from the German National Resource Center for Biological Material (DSMZ). For cultivation of P. putida, basal salt medium without antibiotics as described previously was used (Gagnon et al. 1994). E. coli cells were cultivated in terrific broth (TB) medium (12 g tryptone, $24 \mathrm{~g}$ yeast, $4 \mathrm{~g}$ glycerol in $1 \mathrm{~L}$ buffer autoclaved separately). Overnight cultures were grown in Luria Bertani (LB) medium (10 g tryptone, 5 yeast, $5 \mathrm{~g} \mathrm{NaCl}$ in $1 \mathrm{~L}$ dest $\mathrm{H}_{2} \mathrm{O}$ ). $\mathrm{LB}$ and $\mathrm{TB}$ media were supplemented with $100 \mu \mathrm{g} / \mathrm{mL}$ kanamycin.
Transformation of E. coli strain BL21-DE3 (Novagen, genotype: [95 F- ompT hsdSB (rB-mB-) gal dcmrne131 (DE3)]) with pET-28_2,5-DKCMO was carried out by the heat shock method described by Chung et al. (1989). Expression of recombinant 2,5-DKCMO in E. coli BL21 was performed by cultivation at $37^{\circ} \mathrm{C}$ to an $\mathrm{OD}_{600}$ of 0.5 , than addition IPTG to a final concentration of 0.1 $\mathrm{mM}$ and shifting the culture to $20^{\circ} \mathrm{C}$ and $200 \mathrm{rpm}$ for another $16 \mathrm{~h}$ of cultivation.

\section{Gene expression analysis}

Gene expression analysis was performed with crude cell extract. Samples standardized to cell amount were taken during cultivation. Cells were harvested by centrifugation and resuspended in sodium phosphate buffer (50 $\mathrm{mM}, \mathrm{pH}$ 7.5). Cell disruption was performed by FastPrep (40 s, $4 \mathrm{~m} / \mathrm{s}$; MP Biomedicals, Solon, OH, USA). For SDS-PAGE analysis, the supernatant was substituted with Laemmli buffer (Laemmli 1970). SDS-PAGE was carried out on $12 \%$ resolving gels. Proteins were stained with a Coomassie R250/G250 solution.

\section{Enzyme purification}

Cells were harvested by centrifugation and resuspended in sodium phosphate buffer $(50 \mathrm{mM}, \mathrm{pH} 7.5)$. Cell disruption was performed by a single passage through a French pressure cell. Recombinant 2,5-DKCMO was purified by affinity chromatography via N-terminal Histag on an automated Äkta purifier system. After centrifugation of disrupted cells for $45 \mathrm{~min}$ at $(10,000 \times \mathrm{g})$, the supernatant with recombinant 2,5-DKCMO was added to the column. A $5 \mathrm{~mL}$ HisTrap FF crude column with bound $\mathrm{Ni}^{2+}$ was equilibrated with sodium phosphate buffer (100 mM, pH 7.5) supplemented with 300 $\mathrm{mM} \mathrm{NaCl}$ and $30 \mathrm{mM}$ imidazole. After passing through of the crude extract, the column was washed with three column volumes of sodium phosphate buffer $(100 \mathrm{mM}$, $\mathrm{pH}$ 7.5) supplemented with $300 \mathrm{mM} \mathrm{NaCl}$ and $30 \mathrm{mM}$ imidazole followed by two column volumes of sodium phosphate buffer (100 mM, pH 7.5) supplemented with $300 \mathrm{mM} \mathrm{NaCl}$ and $60 \mathrm{mM}$ imidazole to remove unspecific bound proteins. Elution was performed by adding three column volumes of $300 \mathrm{mM}$ imidazole in sodium phosphate buffer (100 mM, pH 7.5) supplemented with $300 \mathrm{mM} \mathrm{NaCl}$. Fractions of washing and elution steps were collected to analyze purity by SDS-PAGE. In order to remove imidazole and $\mathrm{NaCl}$ from the eluate, the pooled elution fractions were loaded to a $60 \mathrm{~mL}$ size exclusion column (Sephadex G25 matrix), which was equilibrated with sodium phosphate buffer $(50 \mathrm{mM}, \mathrm{pH}$ $7.5)$ before. Proteins fractions were recognized via online absorption measurement at $280 \mathrm{~nm}$ and collected. Determination of protein content of purified and desalted protein as well as crude extract was carried out 


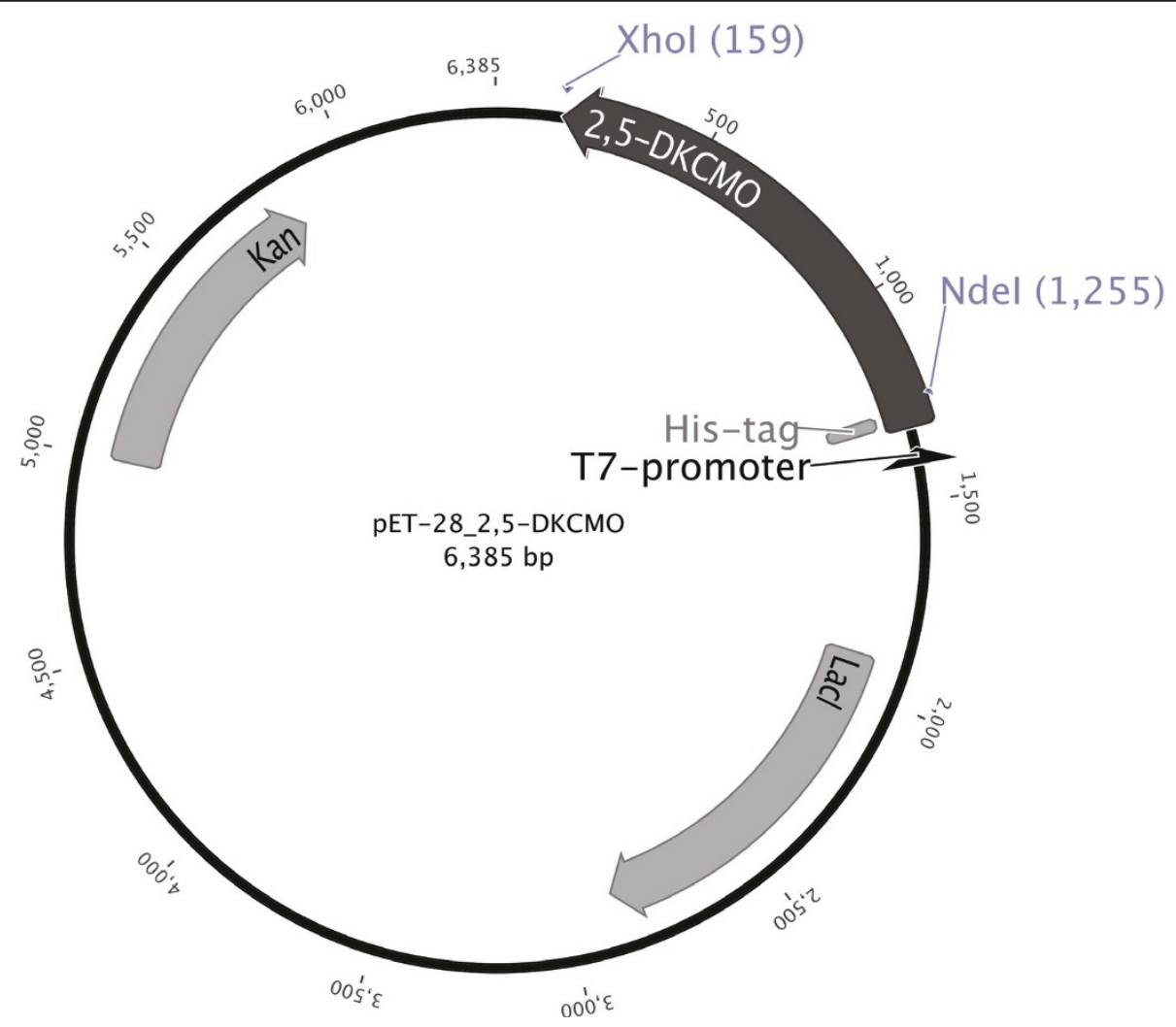

Figure 3 Vector 2,5-DKCMO_pET-28 for expression of recombinant 2,5-DKCMO from P. putida NCIMB 10007 under control of T7 promoter in E. coli BL21. The 2,5-DKCMO-gene was introduced using the sites of restriction endonucleases Ndel and Xhol for cloning.

with the BCA-kit and a standard curve of BSA in the same buffer in a range of $2-0.005 \mathrm{mg} / \mathrm{mL}$ was used. Samples were measured in triplicates in three different dilutions.

\section{Biocatalytic reactions and $\mathrm{GC}$ analysis}

For biocatalysis, His-tag purified 2,5-DKCMO, crude extracts of E. coli BL21 pET28_2,5-DKCMO cultivations and resting cells were used. Reactions were carried out in sodium phosphate buffer $(50 \mathrm{mM}, \mathrm{pH} 7.5)$ Substrates were used in concentrations from $0.5-2 \mathrm{mM}$, the cofactor FMN was used at a final concentration of $0.3 \mathrm{mM}$. NADH was used in equimolar amounts to the substrate. Purified 2,5-DKCMO was employed in concentrations of $1.5-2 \mathrm{mg} / \mathrm{mL}$, crude extracts in concentrations of $12-15 \mathrm{mg} / \mathrm{mL}$. Incubation was performed in 24-well MTP at 800-1000 rpm. Sample volume was $1 \mathrm{~mL}$. Extraction of substrates and products was performed by vortexing of samples with $600 \mu \mathrm{l}$ and $400 \mu \mathrm{l}$ of ethyl acetate subsequently. Samples were dried over anhydrous sodium sulfate. Separation of aqueous and organic phase was done by centrifugation. The organic solvent was evaporated in a vacuum centrifuge. $120 \mu \mathrm{L}$ of fresh EtOAc was added, and samples were analyzed by
GC-MS on a QP 2010 (Shimadzu Europa GmbH, Duisburg, Germany) with a BPX5 column (5\% phenyl-/95\% methylpolysilphenylene siloxane, SGE GmbH, Darmstadt, Germany). Injection temperature was set to $220^{\circ}$ C. Detection temperature for (+)-1, (-)-1, 13, 14 and 15 was $60^{\circ} \mathrm{C}$ for $5 \mathrm{~min}$ followed by a gradient of $10^{\circ} \mathrm{C} / \mathrm{min}$ to $180^{\circ} \mathrm{C}$ maintained for $3 \mathrm{~min}$. Detection temperature for 16 was $120^{\circ} \mathrm{C}$. For $17,240^{\circ} \mathrm{C}$ for 5 min followed by a gradient of $2^{\circ} \mathrm{C} / \mathrm{min}$ to $270^{\circ} \mathrm{C}$ was used and maintained for 5 min. 6-8 were analyzed at $60^{\circ} \mathrm{C} .9$ and 10 were detected isothermal at $160^{\circ} \mathrm{C}$. Detection temperature for 11 was $90^{\circ} \mathrm{C}$ and for $12100^{\circ} \mathrm{C}$.

Specific activity is given in units per milligram $(\mathrm{U} / \mathrm{mg})$ protein. One unit is defined as the amount of enzyme that catalyzes the oxidation of $1 \mu \mathrm{mol}$ of substrate per minute.

\section{Results}

Cloning, expression and purification of 2, 5-diketocamphane 1,2-monooxygenase

The 2,5-diketocamphane 1,2-monooxygenase (2,5DKCMO) from Pseudomonas putida NCIMB 10007 is encoded on the CAM operon on the transmissible $230 \mathrm{~kb}$ CAM plasmid (Rheinwald et al. 1973). First 
chromosomal and plasmid DNA were isolated from the P. putida strain NCIMB 10007 cultivated with camphor as sole carbon source. The gene was then amplified by gradient PCR using gene specific primers derived from the corresponding gene [GenBank: AY450285]. The PCR product was afterwards ligated into the expression vector $\mathrm{pET}-28 \mathrm{~b}$ fused to the $\mathrm{N}$-terminal His-tag to allow a functional expression of the 2,5-DKCMO in E. coli and easy protein purification by affinity chromatography. The $\mathrm{N}$-terminal tag was favored compared to the C-terminal tag, because our experience with 4-hydrocyacetophenonemonooxygenase (HAPMO) from $P$. putida JD1 indicated that BVMO-expression is decreased by the use of C-terminal tags (Rehdorf et al. 2009).

The utilization of E. coli BL21(DE3) as expression host yielded primarily soluble 2,5-DKCMO protein after $16 \mathrm{~h}$ cultivation at $20^{\circ} \mathrm{C}$ in $\mathrm{TB}$ medium, while cultivation at $30^{\circ} \mathrm{C}$ yielded in insoluble inclusion bodies (data not shown). SDS-PAGE analysis of crude cell extract led to a clear band at approx. $40 \mathrm{kD}$ shown in Figure 4, which corresponds to the theoretical estimated molecular weight of $42.9 \mathrm{kD}$ of the His-tagged protein.

After successful recombinant expression, a nickelbased affinity chromatography of the His-tagged protein and the subsequent removal of imidazole by size exclusion chromatography on a G25 column was performed and yielded pure protein (Figure 4, lane 3) with a purification factor of six (Table 1). The fractions containing purified protein were colorless, which confirmed previous studies, in which FMN is not covalently bound to the enzyme (Trudgill 1986).

\section{Substrate specificity of 2,5-DKCMO}

To determine the substrate specificity of 2,5-DKCMO a variety of compounds representing different classes of BVMO-substrates were investigated in biocatalysis experiments using the crude enzyme extract (Figure 5). Only bicyclic ketones were converted under the chosen conditions by the crude extract containing 2,5-DKCMO (Table 2). For all monocyclic ketones (6-8), aromatic ketones (9-11), the aliphatic 2-decanone (12) tested as well as for 1-indanone (16) and progesterone (17) no conversion could be determined. The biocatalysis with substrates, which were converted was further investigated using the pure enzyme and specific activities were determined in biocatalysis experiments in $1 \mathrm{~mL}$ scale with $2 \mathrm{mM}$ of substrates at $25^{\circ} \mathrm{C}$ for $15 \mathrm{~h}$ (Table 2).

Interestingly, in our study (-)-1 was also converted by the 2,5-DKCMO, although purified enzyme isolated from wild-type strain cultivation was claimed to be specific for the (+)-enantiomer (Jones et al. 1993). As we have recombinantly produced the BVMO in the E. coli host, which does not have its own BVMO and the conversion of (-)-camphor was observed with crude cell

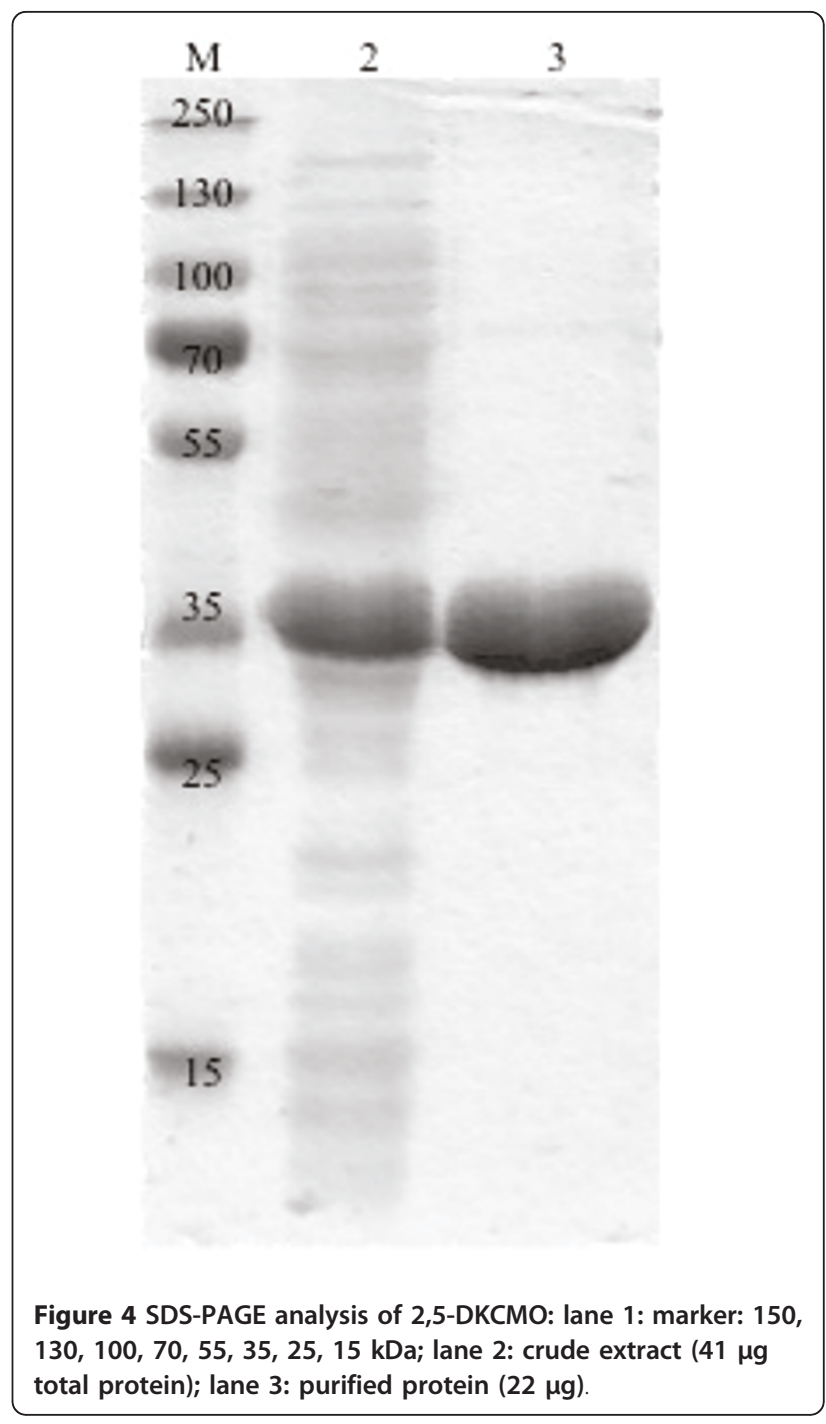

extract as well as His-tag purified protein, we can only speculate whether the purified protein described by Jones et al. 1993 was indeed homogenous. Norcamphor (13) and ( \pm )-cis-bicyclo [3.2.0] hept-2-en-6-one (14) were better accepted as substrates than camphor in general, and furthermore $(R, R)$-bicyclo [2.2.1] heptane2,5-dion (15), which is structurally similar to the natural substrate 2,5-diketocamphane (3), is also converted. In addition, the conversion of $\mathbf{1 4}$ was performed with resting cells expressing 2,5-DKCMO, where $11 \%$ conversion could be observed after $6 \mathrm{~h}$ of biocatalysis at $0.5 \mathrm{mM}$ substrate concentration.

\section{Discussion}

The oxygenating subunit of the 2,5-diketocamphane monooxygenase was successfully cloned and overexpressed recombinantly in E. coli as the heterologous expression host. Hence, this enzyme is now easy 
Table 1 Purification of 2,5-DKCMO via nickel-based affinity chromatography and imidazole removal

\begin{tabular}{|c|c|c|c|c|c|c|c|}
\hline Step & $\begin{array}{c}V \\
{[\mathrm{~mL}]}\end{array}$ & $\begin{array}{c}\text { Volumetric activity }{ }^{\mathrm{a}}[\mathrm{U} / \\
\mathrm{mL}]\end{array}$ & $\begin{array}{l}\text { Activity }^{a} \\
{[U]}\end{array}$ & $\begin{array}{c}\text { Protein amount } \\
\mathrm{mL}]\end{array}$ & $\begin{array}{l}\text { Specific activity [mU/ } \\
\mathrm{mg}]\end{array}$ & $\begin{array}{c}\text { Yield } \\
{[\%]}\end{array}$ & Factor \\
\hline Crude extract & 30 & 0.0021 & 0.063 & 14 & 0.15 & 100 & 1 \\
\hline $\begin{array}{l}\text { Purified and } \\
\text { desalted }\end{array}$ & 7 & 0.0015 & 0.0103 & 1.6 & 0.90 & 16 & 6 \\
\hline
\end{tabular}

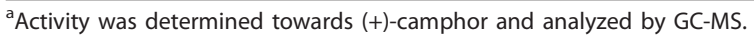

Activity of the purified protein containing imidazole prior to the size exclusion chromatography could not be determined, since imidazole interferes with the used GC-MS column.

${ }^{\mathrm{b}}$ Protein amount as determined by the BCA assay.

available at stable quality and protein engineering studies are possible for the first time. The purification using the $\mathrm{N}$-terminal His-tag via nickel based affinity chromatography turned out to be efficient and fast. While in previous purifications of the enzyme from wild type cultivations, huge culture volumes were used, in this study drastically smaller amounts of heterologous culture is needed to produce comparable amounts of pure protein. Conrad et al. used a $10 \mathrm{~L}$ culture and obtained $240 \mathrm{~mL}$ crude extract to produce $52 \mathrm{mg}$ of pure protein via a chromatography based purification protocol with three steps, which corresponds to a recovery of $15 \%$ (Conrad et al. 1965a,). 28 years later Jones et al. were able to increase the purity and the yield up to $19.5 \%$. From a $10 \mathrm{~L}$ culture volume $49 \mathrm{mg}$ of pure enzyme were obtained (Jones et al. 1993). In this work $8 \mathrm{mg}$ of pure protein were achieved out of a $400 \mathrm{~mL}$ culture, which highlights the advantages of recombinant expression and the fusion of an enzyme to a His-tag.

Previous studies on the purified protein determined a molecular size of 2,5-DKCMO of $78 \mathrm{kDa}$ by native PAGE. Under denaturating conditions two identical subunits with a molecular weight of each $37 \mathrm{kDa}$ were identified (Trudgill 1986). The estimated mass from the amino acid sequence of one subunit of 2,5-DKCMO is $40.7 \mathrm{kDa}$ and fused to the His-tag $42.8 \mathrm{kDa}$. SDS-PAGE analysis of $E$. coli crude extract and pure protein resulted in protein bands corresponding to approx. $40 \mathrm{kDa}$, which corresponds to those molecular weights determined in earlier studies within a certain error range of the SDS-PAGE method.

Fractions containing 2,5-DKCMO collected by affinity chromatography turned out to be colorless. It was previously shown that FMN binding occurs non-covalently (Conrad et al. 1961), and therefore we assume that FMN is lost during the purification process. To achieve better stability of the enzyme, FMN was added to the protein solution immediately.

The requirement of non-heme $\mathrm{Fe}^{2+}$ ions for oxygenating activity was intensively discussed in the past as well (Conrad et al. 1965a). Fe ${ }^{2+}$ was thought to be essential for the generation of the active form of oxygen required for the BVMO reaction. In fact, there are no mechanistic requirements for transition metal-ions in the enzyme, which could also be confirmed by the availability of BVMO-activity of pure protein in the absence of $\mathrm{Fe}^{2+}$ within this study.

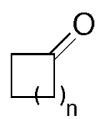

$6 \mathrm{n}=1$

$7 \mathrm{n}=2$

$8 \mathrm{n}=3$

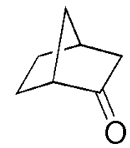

13<smiles>[R]c1ccc(C(C)=O)cc1</smiles>

$9 \mathrm{R}=\mathrm{H}$ $10 \mathrm{R}=\mathrm{OH}$<smiles>O=C1CC2C=CCC12</smiles>

14<smiles>CC(=O)CCc1ccccc1</smiles>

11

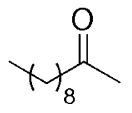

12<smiles>O=C1CC2CC1CC2=O</smiles><smiles>O=C1CCc2ccccc21</smiles>

16

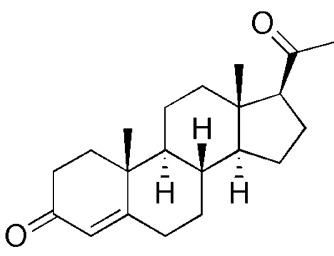

17

Figure 5 Substrates used for 2,5-DKCMO-catalyzed Baeyer-Villiger oxidation. 6-8 represent the monocyclic ketones, 9-11 substitute aromatic ketones, 12 served as an example for aliphatic and 13-16 for bicyclic ketones. 
Table 2 conversion of several bicyclic ketones by crude cell extract and specific activities for pure 2,5-DKCMO

\begin{tabular}{|c|c|c|}
\hline Substrate & Conversion $^{\mathrm{a}}[\%]$ & Specific activity ${ }^{\mathbf{b}}[\mathrm{mU} / \mathrm{mg}]$ \\
\hline (+)-Camphor ((+)-1) & 66 & 0.9 \\
\hline (-)-Camphor ((-)-1) & 25 & 0.3 \\
\hline Norcamphor (13) & 98 & 1.3 \\
\hline 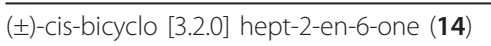 & 100 & 1.4 \\
\hline$(R, R)$-bicyclo [2.2.1] heptane-2,5-dion (15) & 94 & 0.06 \\
\hline
\end{tabular}

${ }^{a}$ Conversion was determined by GC-MS analysis of biocatalysis samples with crude extract from E. coli cells overexpressing DKCMO at a substrate concentration of $1 \mathrm{mM}$ after $23 \mathrm{~h}$.

${ }^{\text {b }}$ Specific activity was calculated from conversion of substrate by pure enzyme determined by GC-MS at different points of time.

In this work, recombinant expression and purification of 2,5-DKCMO, an oxygenating subunit, led to a "dehydrogenase-missing" pure protein and it could be shown that the enzyme is still able to oxidize bicyclic ketones. Previously, marginal BVMO-activity was obtained although no NADH dehydrogenase was detectable in the final preparation of 2,5-DKCMO, which was finally reasoned with impurities or the fact that the oxygen component is able to operate as its own NADH dehydrogenase in presence of FMN and remove electrons from NADH to catalyze the reaction (Trudgill 1986). Low activities of purified oxygenating component were observed earlier as well and were explained by a weak coupling of the mentioned subunits in vitro (Conrad et al. 1965b).

We also observed that oxygenating activity of 2, 5-DKCMO expressed in E. coli is higher in the crude extract or whole cell approaches when compared to pure protein. This fact might be explainable by several components of $E$. coli cells that may substitute the missing NADH dehydrogenase. Coexpression experiments with a suitable NADH dehydrogenase may further improve the activity of 2,5-diketocamphane 1,2-monooxygenase considerably and could thus generate valuable catalysts for organic synthesis providing access to industrial valuable precursors for e.g. azadirachtin.

Regarding the requirement for cofactor regeneration in larger scale applications, the 2,5-DKCMO might also be used in whole cell approaches with the expression system introduced in this report.

\section{Abbreviations}

FMN: flavin mononucleotide; NADH: nicotinamide adenine dinucleotide; BVMO: Baeyer-Villiger monooxygenase; 2,5-DKCMO: 2,5-diketocamphane 1,2monooxygenase

\section{Acknowledgements}

We are grateful to the Deutsche Bundesstiftung Umwelt (DBU, Osnabrück, Germany, Grant No. AZ13234) for financial support and Christin Peters and Ina Menyes for assistance in the laboratory.

\section{Competing interests}

The authors declare that they have no competing interests.

Received: 1 June 2011 Accepted: 23 June 2011 Published: 23 June 2011

\section{References}

Bradshaw WH, Conrad HE, Corey EJ, Gunsalus IC (1959) Microbiological degradation of (+)-camphor. J Am Chem Soc 4492:5507-5507

Chakrabarty AM (1976) Plasmids in Pseudomonas. Ann Rev Genet 10:7-30

Chung CT, Niemela SL, Miller RH (1989) One step preparation of competent Escherichia coli - Transformation and storage of bacterial cells in same solution. Proc Natl Acad Sci USA 86:2172-2175

Conrad HE, DuBus R, Namvedt M, Gunsalus IC (1965a) Mixed function oxidations II: separation and propertiers of the enzymes catalyzing camphor lactonization. J Biol Chem 240:495-503

Conrad HE, Lieb K, Gunsalus IC (1965b) Mixed function oxidation III: An electron transport complex in camphor ketolactonization. J Biol Chem 240:4029-4037

Conrad IE, Dubus R, Gunsalus IC, York N (1961) An enzyme system for cyclic ketone lactonization. Biochem Bioph Res Co 6:293-297

Fraaije MW, Wu J, Heuts DPHM, van Hellemond EW, Spelberg JHL, Janssen DB (2005) Discovery of a thermostable Baeyer-Villiger monooxygenase by genome mining. Appl Microbiol Biot 66:393-400. doi:10.1007/s00253-0041749-5.

Gagnon R, Grogan G, Groussain E, Pedragosa-Moreau S, Richardson PF, Roberts SM, Willetts AJ, Alphand V, Lebreton J, Furstoss R (1995a) Oxidation of some prochiral 3-substituted cyclobutanones using monooxygenase enzymes: A single-step method for the synthesis of optically enriched 3substituted $\gamma$-lactones. J Chem Soc Perkin Trans 1:2527-2528

Gagnon R, Grogan G, Levitt MS, Peter MR, Willetts AJ (1994) Biological BaeyerVilliger oxidation of some monocyclic and bicyclic ketones using monooxygenases from Acinetobacter calcoaceticus NCIMB 9871 and Pseudomonas putida NCIMB 10007. J Chem Soc Perkin Trans 1:2537-2543

Gagnon R, Grogan G, Roberts SM, Villa R, Willetts AJ (1995b) Enzymatic BaeyerVilliger oxidations of some bicyclo[2.2.1] heptan-2-ones using monooxygenases from Pseudomonas putida NCIMB 10007: Enantioselective preparation of a precursor of Azadirachtin. J Chem Soc Perkin Trans 1:1505-1505. doi:10.1039/p19950001505.

Grogan G, Roberts SM, Wan PWH, Willetts AJ (1993) Camphor grown Pseudomonas putida, a multifunctional biocatalyst for undertaking BaeyerVilliger monooxygenase-dependent biotransformations. Biotechnol Lett 15:913-918

Jones KH, Smith RT, Trudgill PW (1993) Diketocamphane enantiomer-specific 'Baeyer-Villiger' monooxygenases from camphor-grown Pseudomonas putida ATCC 17453. J Gen Microbiol 139:797-805

Koga H, Yamaguchi E, Matsunaga K, Aramaki H, Horiuchi T (1989) Cloning and nucleotide sequences of NADH-putidaredoxin reductase gene (camA) and putidaredoxin gene (camB) involved in cytochrome P-450cam hydroxylase of Pseudomonas putida. J Biochem 106:831-836

Laemmli UK (1970) Cleavage of structural proteins during the assembly of the head of bacteriophage T4. Nature 227:680-685

Meinwald J, Frauenglass (1960) The Baeyer-Villiger oxidation of bicyclic ketones. J Am Chem Soc 82:5235-5239. doi:10.1007/bf01086344.

Ougham HJ, Taylor DG, Trudgill PW (1983) Camphor revisited: Involvement of a unique monooxygenase in metabolism of 2-oxo- $\triangle^{3}-4,5,5-$ trimethylcyclopentenylacetic acid by Pseudomonas putida. J Bacteriol 153:140-152

Rehdorf J, Kirschner A, Bornscheuer UT (2007) Cloning, expression and characterization of a Baeyer-Villiger monooxygenase from Pseudomonas putida KT2440. Biotechnol Lett 29:1393-1398. doi:10.1007/s10529-007-9401-y.

Rehdorf J, Zimmer CL, Bornscheuer UT (2009) Cloning, expression, characterization, and biocatalytic investigation of the 
4-hydroxyacetophenone monooxygenase from Pseudomonas putida JD1. Appl Environ Microb 75:3106-3114. doi:10.1128/aem.02707-08.

Rheinwald JG, Chakrabarty AM, Gunsalus IC (1973) A transmissible plasmid controlling camphor oxidation in Pseudomonas putida. Proc Natl Acad Sci USA 70:885-889

Trudgill PW (1986) Camphor revisited: Studies of 2,5-diketocamphane 1,2monooxygenase from Pseudomonas putida ATCC 17453. J Bacteriol 165:489-497

Unger BP, Gunsalus RP, S SG (1986) Nucleotide sequence of the P. putida cytochrome P-450cam gene and its expression in Escherichia coli. J Biol Chem 261:1158-1163

Völker A, Kirschner A, Bornscheuer UT, Altenbuchner J (2008) Functional expression, purification, and characterization of the recombinant BaeyerVilliger monooxygenase MekA from Pseudomonas veronii MEK700. Appl Microbiol Biot 77:1251-1260. doi:10.1007/s00253-007-1264-6.

doi:10.1186/2191-0855-1-13

Cite this article as: Kadow et al: Recombinant expression and

purification of the 2,5-diketocamphane 1,2-monooxygenase from the camphor metabolizing Pseudomonas putida strain NCIMB 10007. AMB Express 2011 1:13

\section{Submit your manuscript to a SpringerOpen ${ }^{\circ}$ journal and benefit from:}

- Convenient online submission

- Rigorous peer review

- Immediate publication on acceptance

- Open access: articles freely available online

- High visibility within the field

- Retaining the copyright to your article

Submit your next manuscript at $\gg$ springeropen.com 